\title{
Simmel e as cidades históricas italianas - Uma introdução
}

Carlos Fortuna

\section{(2) OpenEdition \\ Journals}

Edição electrónica

URL: http://journals.openedition.org/rccs/1659

DOI: $10.4000 /$ rccs. 1659

ISSN: 2182-7435

Editora

Centro de Estudos Sociais da Universidade de Coimbra

\section{Edição impressa}

Data de publição: 1 Dezembro 2003

Paginação: 101-107

ISSN: 0254-1106

\section{Refêrencia eletrónica}

Carlos Fortuna, "Simmel e as cidades históricas italianas - Uma introdução », Revista Crítica de Ciências Sociais [Online], 67 | 2003, colocado online no dia 01 outubro 2012, criado a 19 abril 2019. URL : http://journals.openedition.org/rccs/1659; DOI : 10.4000/rccs.1659

Este documento foi criado de forma automática no dia 19 Abril 2019.

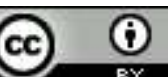




\title{
Simmel e as cidades históricas italianas - Uma introdução
}

\author{
Carlos Fortuna
}

1 Por vontade expressa do autor, o artigo não está disponível em versão electrónica.

\section{INDEX}

Palavras-chave: cidade, arte, estética, Roma, Florença, Veneza, Itália, cidades históricas Mots-clés: ville, art, esthétique, Rome, Florence, Venise, Italie, villes historiques Keywords: city, aesthetics, Venice, Italy, historical towns

\section{AUTHOR}

\section{CARLOS FORTUNA}

Professor catedrático da Faculdade de Economia da Universidade de Coimbra e investigador permanente do Centro de Estudos Sociais, onde coordena o Núcleo de Estudos sobre Cidades e Culturas Urbanas. Publicações recentes: Projecto e circunstância. Culturas urbanas em Portugal, Porto, Afrontamento, 2002 (co-org. com Augusto Santos Silva); “Culturas urbanas e espaços públicos: sobre as cidades e a emergência de um novo paradigma sociológico", Revista Crítica de Ciências Sociais, 63, 2002, 125-150.

cfortuna@fe.uc.pt 